\title{
THE EFFECT OF THE BI RATE STANDARD ON THE BRI SHARIA MARGIN POLICY 2015-2019
}

\author{
Isti Tresna Aristantia \\ Institut Agama Islam Darussalam (IAID) Ciamis-Jawa Barat \\ Email: isti.tresnaaristantia@gmail.com \\ Suci Sulastri \\ Institut Agama Islam Darussalam (IAID) Ciamis-Jawa Barat
}

\begin{abstract}
This research is motivated by the absence of provisions governing the determination of financing margins, making Islamic banks in Indonesia, namely Bank Rakyat Indonesia Syariah, still use the BI Rate as one of the references in determining margins in financing. The decline in financial conditions can be seen from the net income margin in 2014, which only reached $6.04 \%$. The method used is a descriptive correlational method. The data used is the average BI Rate per year and the 2015-2019 BRI Syariah Annual Report. Data collection techniques used document studies and literature studies with browsing data collection instruments. Data analysis used descriptive statistics, regression, correlation, partial test, and determination. The results of the research data description of the BI Rate and the financing margin income of Bank Rakyat Indonesia Syariah in 2015-2019 experienced an increase and decrease. The results of the analysis of the influence of the BI Rate on financing margin income at Bank Rakyat Indonesia Syariah in 2015-2019 obtained the regression equation: Financing Margin Income $=10.45376+(-0.568777 \times$ BI Rate $)+$ e. The correlation coefficient value is -0.79 or $79 \%$. The accepted hypothesis is Ho, which means that there is no significant positive effect between the BI Rate on financing margin income at Bank Rakyat Indonesia Syariah 2015-2019. The conclusion is that the BI Rate does not significantly affect financing margin income at Bank Rakyat Indonesia Syariah 2015-2019.
\end{abstract}

\begin{abstract}
Abstrak
Penelitian ini dilatarbelakangi oleh belum adanya ketentuan yang mengatur penentuan margin pembiayaan menjadikan bank syari'ah di Indonesia yaitu Bank Rakyat Indonesia Syariah masih menjadikan BI Rate sebagai salah satu rujukan dalam penetapan margin dalam pembiayaan. Penurunan kondisi keuangan tersebut terlihat dari net income margin pada tahun 2014 yang hanya mencapai 6,04\%. Metode yang digunakan adalah metode deskriptif korelasional. Data yang digunakan adalah data BI Rate rata-rata per tahun dan Annual Report BRI Syariah tahun 2015-2019. Teknik pengumpulan data menggunakan studi dokumen dan studi kepustakaan dengan instrumen pengumpulan data browsing. Analisis data menggunakan statistik deskriptif, regresi, korelasi, uji parsial, dan determinasi. Hasil deskripsi data penelitian BI Rate dan pendapatan margin pembiayaan Bank Rakyat Indonesia Syariah tahun 2015-2019 mengalami pergerakan kenaikan dan penurunan. Adapun Hasil analisis pengaruh BI Rate terhadap pendapatan margin pembiayaan pada Bank Rakyat Indonesia Syariah tahun 2015-2019 diperoleh persamaan regresi: Pendapatan Margin Pembiayaan $=10.45376+(-0.568777 \times$ BI Rate $)+$ e. Nilai koefisien korelasi sebesar 0,79 atau $79 \%$. Hipotesis yang diterima adalah Ho yang berarti tidak ada pengaruh yang positif signifikan antara BI Rate terhadap pendapatan margin pembiayaan pada Bank Rakyat Indonesia Syariah tahun 2015-2019. Kesimpulannya adalah BI Rate tidak
\end{abstract}


berpengaruh secara positif signifikan terhadap pendapatan margin pembiayaan pada Bank Rakyat Indonesia Syariah tahun 2015-2019.

Keywords: Mudharabah, Fatwa DSN dan Fath al-Mu'in'

\section{Introduction}

A sharia bank is based on the principles of partnership, fairness, transparency, and universality and carries out banking business activities based on sharia principles (Susyanti, 2016: 45). According to Sharia principles, the characteristics of business activities include the prohibition of usury, not recognizing the concept of the time value of money, and not engaging in speculative activities. Financing is one of the activities of Islamic banks that are directly related to the real sector. The funding is divided into the principle of buying and selling, profit sharing, and leasing. The profit obtained by Islamic banks by channeling the principle of buying and selling financing is in the form of margin. Margin is determined at the beginning of the agreement with the agreement of both parties. Financing margin income is the profit obtained from the results of buying and selling activities, the amount determined at the beginning of the contract following the agreed agreement.

The prohibition of usury as the implementation of sharia principles makes sharia bank operations not based on interest. Because there are no provisions governing the determination of the financing margin, Islamic banks in Indonesia, such as Bank Rakyat Indonesia Syariah, still use the BI Rate as one of the references in determining margins in financing. However, the financing margin at Islamic banks is often higher than the interest rate at conventional banks. It is done to anticipate the unstable BI Rate and inflation.

The results of Adi's research (2013: 105), which examines the factors that influence the income of the murabahah financing margin at Bank Rakyat Indonesia Syariah and Bank Mega Syariah in 2009-2012 found that the BI Rate had a significant negative effect on murabahah income. The absence of provisions governing the determination of the financing margin has made Islamic banks in Indonesia, namely Bank Rakyat Indonesia Syariah, still use the BI Rate as one of the references in determining margins in financing. In addition, the unfavorable macroeconomic conditions in Indonesia in 2014 impacted the business of BRI Syariah financing customers, resulting in a decline in financial needs. The reduction in economic conditions can be seen from the net income margin in 2014, which only reached $6.04 \%$. It makes researchers interested in knowing more about the influence of the BI Rate on financing margin income at Bank Rakyat Indonesia Syariah.

\section{Theoretical Review}

Based on Law no. 21 chapter I article 1 paragraph 7 of 2008 concerning Sharia Banking, sharia banks are banks that carry out their business activities based on sharia principles and by type consist of sharia commercial banks and sharia people financing banks (Law No. RI Law, 2008: 3). Sharia bank is a bank that operates without relying on interest (Muhammad, 2005: 1). In other words, Islamic banks are financial institutions whose operations are adjusted to Islamic sharia principles. The birth of this sharia bank made Muslims avoid the interest system, usury transactions, and other transactions prohibited by Islamic sharia.

According to Puspopranoto (2004: 60) the BI Rate is "An interest rate with a tenor of 1 month announced by Bank Indonesia periodically for a certain period of time which serves as a signal or monetary policy stance". Meanwhile, according to the Bank 
Indonesia dictionary, the BI Rate is a policy interest rate that reflects the monetary policy stance or stance set by BI and announced to the public. The Bank Indonesia interest rate (SBI) or BI Rate is the interest rate for the signaling instrument of Bank Indonesia (BI), which is the monetary policy rate (policy rate) which is used as a reference in the implementation of monetary control operations to direct the weighted average of the SBI interest rates. One month from the Open Market Operation (OPT) auction, the interest rate for liquidity adjustment instruments is around the BI Rate (Affandi, 2016: 51).

Revenue is a gross profit or inflow from the normal activities of the company or bank that are run. Revenue is an appalling increase in assets or a decrease in liabilities or a combination of both during the period selected by the statement of opinion resulting from lawful investment, trading, providing services, or other activities aimed at making a profit, such as limited investment account management (Antonio, 2009). : 204).

Margin or profit is the value obtained by the bank in carrying out its operations. Margin in banking is obtained from buying and selling transactions, namely murabahah, salam, and istishna' transactions. From the above understanding, it can be concluded that the financing margin income is the profit obtained from the results of buying and selling activities, namely murabahah, salam, and istishna', the amount of which has been determined at the beginning of the contract following the agreed agreement.

\section{Methods}

This type of research is quantitative with a descriptive correlational research method. Correlational descriptive method is a research method by describing or describing the object under study to know the relationship between the variables. The object of this research is Bank Rakyat Indonesia Syariah for the period 2015-2019. The population of this research is the Annual Report of Bank Rakyat Indonesia Syariah in 2008-2016. The sample of this research is the Annual Report of Bank Rakyat Indonesia Syariah 2015-2019. This study uses two variables, namely the BI Rate as an independent variable and financing margin income as the dependent variable. The data collection technique used is the study of documents and literature. The data used in this study is panel data (pooled data). Panel data is a combination of time series data and cross-section data. The combined data in question consists of data on the average BI Rate of Bank Indonesia for the 2015-2019 period and data on financing margin income for Bank Rakyat Indonesia Syariah 2015-2019.

The instrument of data collection in this study was by browsing. Browsing is an activity to find information through a web browser. The information sought is the BI Rate data for 2015-2019 from the web www.bi.go.id and the 2015-2019 annual financial report of Bank Rakyat Indonesia Syariah from the web www.brisyariah.co.id.

Data analysis is an activity to process research data to obtain a conclusion, this is done to answer the problem formulation and test the hypothesis that has been proposed. To make it easier to analyze the data, the researcher used the Eviews 8 program.

\section{Results and Discussion}

The object of this research is Bank Rakyat Indonesia Syariah. Bank Rakyat Indonesia Syariah is a sharia bank with the third-largest assets in Indonesia. Based on the 2016 Annual Report, Bank Rakyat Indonesia Syariah recorded assets of Rp 24.23 
trillion, or an increase of 19.1\% from Rp 20.34 trillion recorded in 2014. In addition, Bank Rakyat Indonesia Syariah is also a sharia bank that touches the lower middle class.

Descriptive statistics are statistics that function to describe or provide an overview of the object under study through sample or population data as it is. The following are the results of the descriptive statistics of Bank Indonesia's BI Rate for 2015-2019 using Eviews 8:

Table 1. Descriptive Statistics of the BI Rate of Bank Indonesia 2015-2019

\begin{tabular}{lr}
\hline & BI_RATE \\
\hline Mean & 6.772000 \\
Median & 6.580000 \\
Maximum & 7.530000 \\
Minimum & 5.770000 \\
Std. Dev. & 0.753704 \\
Observations & 5 \\
\hline
\end{tabular}

Based on table 1 the results of descriptive statistics on BI Rate data from Bank Indonesia for the $2015-2019$ period, the average (mean) is $6.772 \%$, and the median is $6.58 \%$. The highest achievement (maximum) in 2014 was $7.53 \%$, and the lowest achievement (minimum) in 2012 was $5.77 \%$. The standard deviation (Std. deviation) was obtained at $0.753704 \%$, and the observation data was 5 .

The descriptive statistics of Bank Rakyat Indonesia Syariah financing margin income for 2015-2019 are as follows.

Table 2. Descriptive Statistics of Bank Rakyat Indonesia Syariah Financing Margin Income for 2015-2019

\begin{tabular}{lr}
\hline & Financing Margin Income \\
\hline Mean & 6.602000 \\
Median & 6.380000 \\
Maximum & 7.330000 \\
Minimum & 6.040000 \\
Std. Dev. & 0.537559 \\
Observations & 5 \\
\hline
\end{tabular}

Based on table 2, the results of descriptive statistics on the financing margin income of Bank Rakyat Indonesia Syariah for the 2015-2019 period obtained an average (mean) of $6.602 \%$ and a median of $6.38 \%$. The highest achievement (maximum) in 2012 was $7.33 \%$, and the lowest (minimum) in 2012 was $6.04 \%$. The standard deviation (Std. deviation) is 0.537559 , and the observation data is 5 . This study aimed to determine the effect of the BI Rate on financing margin income at Bank Rakyat Indonesia Syariah 2015-2019. Before performing simple linear regression testing, the research variables were tested whether they met the classical assumptions of the regression equation or not. The normality test used is the Jarque-Bera test. The results of the calculation of the Jarque-Bera normality test are as follows. 
Table 3. Normality Test Jarque-Bera
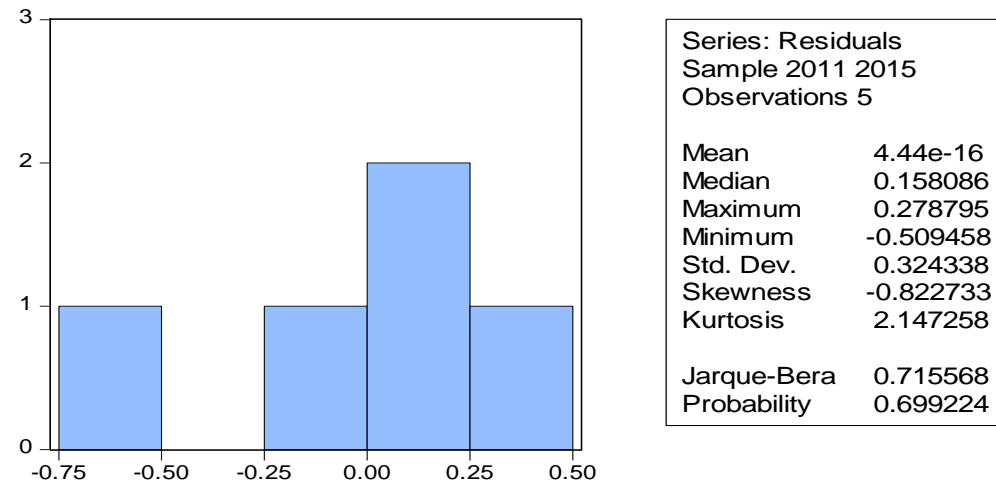

Based on table 3, it can be seen that the data in this study were normally distributed. It can be seen from the probability value of 0.69 , which is greater than the error degree of $5 \%$ (0.05). So it can be concluded that the regression model is normally distributed and can be continued to the next test.

The autocorrelation test is used to see a relationship between the errors of a series of observations ordered by time (time series data). The autocorrelation test method used is the Durbin-Watson test (DW test). The results of the Durbin-Watson autocorrelation test calculation are as follows.

\section{Table 4. Autocorrelation Durbin-Watson}

Dependent Variable: PENDAPATAN_MARGIN_PEMBIA

Method: Least Squares

Date: 08/02/17 Time: 12:57

Sample: 20112016

Included observations: 5

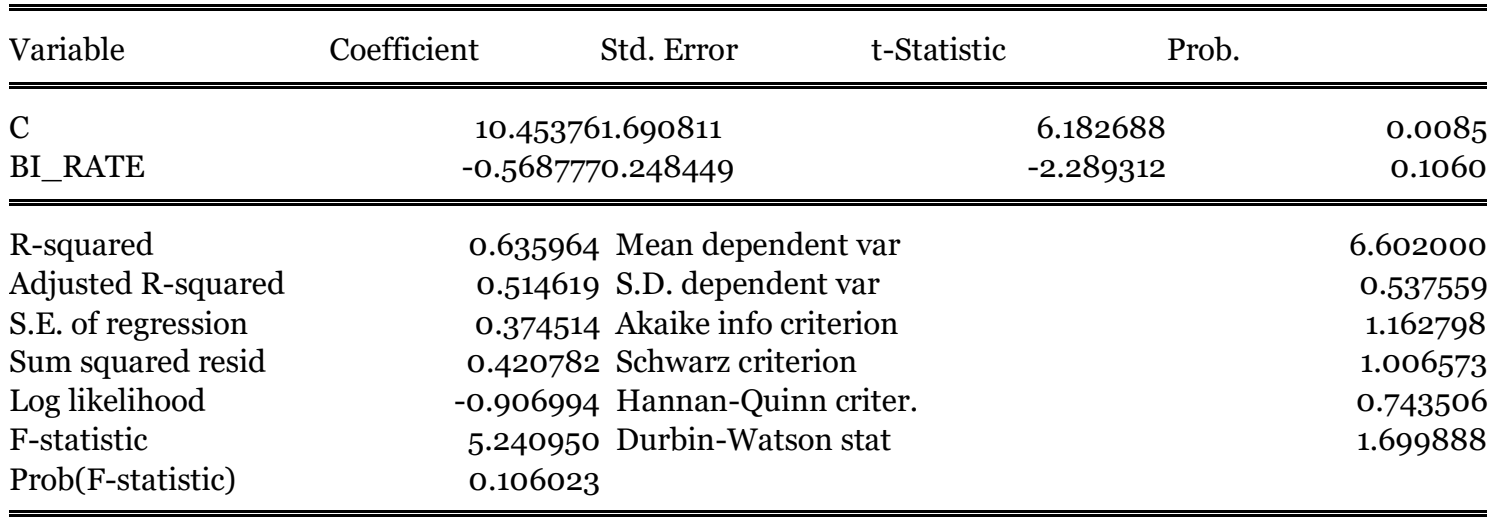

Based on table 4, it can be seen that the Durbin-Watson test value is 1.69. The value is between -2 to +2 , which means no autocorrelation. So it can be concluded that the research data does not have autocorrelation, so the regression model is good to use.

The heteroscedasticity test tests the occurrence of disturbances that appear in the regression function with unequal variances. The heteroscedasticity test method used is the Glejser test. The results of the calculation of the Glejser heteroscedasticity test are as follows. 
Table 5. Heteroskedasticity Test Glejser

Heteroskedasticity Test: Glejser

\begin{tabular}{lllll}
\hline \hline Variable & Coefficient & Std. Error & t-Statistic & Prob. \\
\hline \hline C & 0.612294 & 0.766534 & 0.798782 & 0.4828 \\
BI_RATE & -0.052594 & 0.112635 & -0.466938 & 0.6724 \\
\hline \hline
\end{tabular}

Based on table 5 , the Glejser test value is 0.67 . The value of 0.67 is greater than the $5 \%$ error degree (0.05). So it can be concluded that the research data does not have heteroscedasticity or the research data has homoscedasticity, so the regression model is good to use. After performing a series of classical assumption tests, the data obtained are normally distributed, there is no autocorrelation, and heteroscedasticity, then the data that has been collected can be analyzed using a simple linear regression method. Based on the results of data processing using Eviews 8 in table 1.5, it can be seen that the simple linear regression equation for the research data used is as follows:

Financing Margin Income $=10.45376+(-0.568777$ x BI Rate $)+\mathrm{e}$

The correlation analysis in this study aims to determine the direction and strength of the relationship between the BI Rate and the financing margin income of Bank Rakyat Indonesia Syariah in 2015-2019. This study uses Product Moment correlation analysis because the two variables are in the form of ratios and the data is normally distributed. Based on the data processing of the Product Moment correlation analysis as follows:

Table 6. Product Moment Correlation

\begin{tabular}{lrr}
\hline & BI_RATE & PENDAPATAN_MARGIN_PEMBIA \\
\hline BI_RATE & 1 & -0.7974737057330881 \\
PENDAPATAN_MARGIN_PEMBIA & -0.7974737057330881 & 1 \\
\hline
\end{tabular}

Based on the results of data processing using Eviews 8 in table 1.7, it can be seen that the correlation coefficient between the BI Rate and the financing margin income of Bank Rakyat Indonesia Syariah in $2015-2019$ is -0.79 or $79 \%$. The t-test is used to test the hypothesis about the partial effect of the independent variables on the dependent variable, in this study the effect of the BI Rate on the financing margin income of Bank Rakyat Indonesia Syariah in 2015-2019.

The hypotheses of this research are there is no significant positive effect between the BI Rate on financing margin income at Bank Rakyat Indonesia Syariah in 2015-2019. Ha: There is a significant positive effect between the BI Rate on financing margin income at Bank Rakyat Indonesia Syariah in 2015-2019.

Based on table 4, the analysis of the partial influence of the BI Rate on financing margin income at Bank Rakyat Indonesia Syariah in 2015-2019 the results of hypothesis testing obtained a t-count value of $-2.289|2.289|$. With $n-1(5-1=4)$, the $t$ table is 2.776. It shows that the $\mathrm{t}$ value is $2.289<\mathrm{t}$ table value is 2.776 with a significant level of $0.106>0.05$, then $\mathrm{H}_{1}$ is rejected, which means that there is no significant positive effect between the BI Rate on financing margin income at Bank Rakyat Indonesia Syariah in 2015- 2019. 
Based on the results of simple linear regression in table 1.5 using the Least Squares method, the R-Squared value is 0.63 or $63 \%$, and the Adjusted R-Squared value is 0.51 or $51 \%$. The value of the Adjusted R-Squared shows that the ability of the independent variable BI Rate of Bank Indonesia in explaining the dependent variable of financing income for Bank Rakyat Indonesia Syariah 2015-2019 is 0.51 (51\%), while the remaining 0.49 (49\%) explained by other variables outside the research variables.

This study uses Bank Indonesia's 2015-2019 BI Rate data as the independent variable and 2015-2019 Bank Rakyat Indonesia Syariah financing margin income as the dependent variable. This study aimed to determine the effect of the BI Rate on financing margin income at Bank Rakyat Indonesia Syariah 2015-2019.

Results The formulation of the simple linear regression equation in this study is as follows: $\mathrm{Y}=\mathrm{a}+\mathrm{bX}+\mathrm{e}$

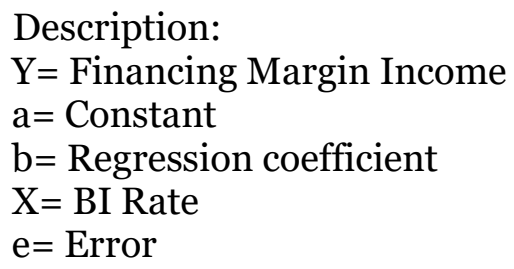

Financing Margin Income $=10.45376+(-0.568777$ x BI Rate $)+e$

From the simple linear regression equation above, it can be explained that: (1) The constant of 10,45376 states that if there is no BI Rate, the financing margin income of Bank Rakyat Indonesia Syariah for 2015-2019 is 10,45376. (2) The X regression coefficient of -0.568777 states that every decrease in the BI Rate by 1 will increase the value of Bank Rakyat Indonesia Syariah financing margins for 2015-2019 by 0.568777. On the other hand, if the BI Rate increases by 1, then the financing margin income of Bank Rakyat Indonesia Syariah in 2015-2019 is predicted to decrease by 0.568777. (3) The sign (+) indicates the direction of the unidirectional relationship, while the sign (-) indicates the direction of the inversely proportional relationship between the independent variable $(\mathrm{X})$ and the dependent variable $(\mathrm{Y})$.

The result of the Product Moment correlation between the BI Rate and the financing margin income of Bank Rakyat Indonesia Syariah for 2015-2019 is -0.79 or $79 \%$. This means that the BI Rate with the financing margin income of Bank Rakyat Indonesia Syariah in 2015-2019 has a strong relationship in a negative direction. Correlation that has a negative direction means that the variables change in the opposite direction. This means that if the BI Rate increases, the financing margin will decrease and if the BI Rate decreases, the financing margin will increase at Bank Rakyat Indonesia Syariah in 2015-2019.

This study accepts the Ho hypothesis which states that the BI Rate does not have a significant positive effect on financing margin income at Bank Rakyat Indonesia Syariah 2015-2019, this is because Bank Rakyat Indonesia Syariah customers are a rational group. This means that the customer knows that if the BI Rate is high, the Islamic bank will set a high margin as well, so that the customer chooses not to finance the buying and selling principle in that period. This makes the volume of financing for buying and selling principles low and results in low financing margin income. On the other hand, if the BI Rate is low, Islamic banks will set a low margin so that customers choose to buy and sell financing in that period. This makes the volume of financing the principle of buying and selling high and resulting in high financing margin income. In addition, customers who are less loyal to Islamic banks are affected by fluctuations in the BI Rate. 
Starting from the acquisition of PT. Bank Rakyat Indonesia (Persero), Tbk., against Bank Jasa Arta on 19 December 2007 and after obtaining permission from Bank Indonesia on 16 October 2008 through its letter o.10/67/KEP.GBI/DpG/2008, then on 17 November 20082008 PT. BRI Syariah Bank is officially operating. Then PT. Bank BRI Syariah changed its business activities which were originally conventionally operational, then converted into banking activities based on Islamic sharia principles.

The presence of PT. Bank BRI Syariah in the midst of the national banking industry is emphasized by the meaning of the glow that follows the company logo. This logo illustrates the wishes and demands of the community for a modern bank of the same class as PT. BRI Syariah Bank that is able to serve the community in modern life. The color combination used is a derivative of blue and white as a red thread with the brand PT. Bank Rakyat Indonesia (Persero), Tbk.

Activities of PT. Bank BRI Syariah became stronger after signing the deed of separation of the Sharia Business Unit of PT. Bank Rakyat Indonesia (Persero), Tbk., to merge into PT. Bank BRI Syariah (spin off process) which took effect on January 1, 2009. The signing was carried out by Mr. Sofyan Basir as the President Director of PT. Bank Rakyat Indonesia (Persero), Tbk., and Mr. Ventje Rahardjo as the President Director of PT. BRI Syariah Bank.

Currently PT. Bank BRI Syariah is the third largest Islamic bank by assets. PT. Bank BRI Syariah is growing rapidly in assets, total financing and obtaining third party funds. By focusing on the lower middle segment, PT. Bank BRI Syariah targets to become a leading modern retail bank with a variety of banking products and services. In accordance with its vision, currently PT. Bank BRI Syariah pioneered a synergy with PT. Bank Rakyat Indonesia (Persero), Tbk., by utilizing the network of PT. Bank Rakyat Indonesia (Persero), Tbk., as a Sharia Service Office in developing a business that focuses on raising public funds and consumer activities based on sharia principles.

\section{Conclusion}

This study accepts the Ho hypothesis which states that the BI Rate does not have a significant positive effect on financing margin income at Bank Rakyat Indonesia Syariah 2015-2019, this is because Bank Rakyat Indonesia Syariah customers are a rational group. This means that the customer knows that if the BI Rate is high, the Islamic bank will set a high margin as well, so that the customer chooses not to finance the buying and selling principle in that period. This makes the financing volume for buying and selling principles low and results in low financing margin income. On the other hand, if the BI Rate is low, Islamic banks will set a low margin to choose to buy and sell financing in that period. It makes the financing volume the principle of buying and selling high and results in high financing margin income. In addition, customers who are less loyal to Islamic banks are affected by fluctuations in the BI Rate.

\section{REFERENCES}

Adi, Muhammad Izzuddin Kurnia. (2013). Faktor-faktor yang mempengaruhi pendapatan margin pembiayaan murabahah pada Bank Rakyat Indonesia Syariah dan Bank Mega Syariah. Skripsi Program Studi Ekonomi Ilmu Islam, Fakultas Syariah dan Hukum Universitas Islam Negeri Sunan Kalijaga, Yogyakarta, 18 Juni 2013.

Affandi, Faisal. (2016). Analisis pengaruh tingkat inflasi, nilai tukar Bi Rate dan suku bunga bank konvensional terhadap margin bagi hasil deposito mudharabah 
perbankan syariah di Indonesia periode 2010-2016. At-Tawassuth, Vol. 1, No. 1, 2016: 45-72.

Antonio, Muhammad Syafi'i. (2009). Bank Syariah dari Teori ke Praktik. Jakarta: Gema Insan Press.

Muhammad. (2005). Manajemen pembiayaan bank syariah. Yogyakarta: UPP AMP YKPN.

Puspopranoto, Sawaldjo. (2004). Keuangan perbankan dan pasar keuangan. Jakarta: Pustaka LP3ES.

Sugiyono. (2013). Statistika untuk penelitian. Bandung: Alfabeta.

Susyanti, Jeni. (2016). Pengelolaan lembaga keuangan syariah. Malang: Empat Dua.

UU RI. (2008). Undang-undang nomor 21 tahun 2008 tentang perbankan syariah. Jakarta. 
